OSLa $\begin{aligned} & \text { Binyam Sisay Mendisu \& Janne Bondi Johannessen (eds.) Multilingual Ethiopia: Linguistic Chal- } \\ & \text { lenges and Capacity Building Efforts, Oslo Studies in Language 8(1), 2016. 109-136. (ISSN 1890- }\end{aligned}$
http://www. journals.uio.no/osla

\title{
ASPECTS OF THE MORPHOPHONOLOGY OF
}

\author{
HAMAR
}

MOGES YIGEZU

\section{ABSTRAC T}

Hamar is a member of the Aroid group of languages spoken by around 46,000 individuals (CSA 2008). The Hamar live in the plain lands of the semi-desert region of the rift valley in the south western corner of Ethiopia, in the South Omo Zone of the Southern Nations, Nationalities and Peoples Region (SNNPR). Their subsistence can be characterized as a mixture of pastoralism and shifting agriculture. The earliest attempts at describing the language were made available through the publications of Conti Rossini (1927) and Da Trento (1941), who provided a few comparative lists of words and grammatical sketches. Over the last few decades, however, some progress has been made in describing aspects of the structure of the language, and these include: Lydall (1976, 1988, 2000), Mary (1987), Getahun (1991), Cupi et al (2013), Binyam \& Moges (2014), and Moges \& Binyam (2015). Only Lydall (1976), Mary (1987) and Moges \& Binyam (2015) briefly described the phonology, the latter with the aim of designing an orthography for the envisaged mother tongue education in the Hamar language. This contribution is a follow up to these previous efforts and it tries to describe aspects of the morphophonology of Hamar. In doing so, the paper gives a concise summary of the sound pattern of the language, focusing on the syllable structure, phonotactic constraints and word structure conditions that regulate the morphophonemic alternations. Three processes are found to be widespread in the morphophonology of the language: the spreading of nasality, the spreading of place of articulation and the spreading of manner of articulation. While nasality spreads from right to left, the spreading of place and manner features takes place from left to right.

\section{[1] INTRODUCTION}

This paper describes the morphophonology of Hamar language. The term morphophonology is used here to refer to the description and analysis of morphophonemic alternations (Trask 1996:229) prevalent in the Hamar language. It also gives a concise description of the sound pattern of Hamar, as a background to the discussion on the morphophonemic alternations exhibited in Hamar word formation processes.

The Hamar live in the rift valley region of south western Ethiopia and their 
territory stretches from the lower Omo valley in the west across the rift valley of Chew Bahir in the east. To the south their border coincides with the Dassanach and the Kenyan border and to the north they are bordered by their closest kins - the Benna and the Aari.

The language is called Hamar Apo by its speakers, which means "mouth of the Hamar". The Hamar use different names to refer to their neighbours. Murso for the Surmic Mursi, Bume for the Nilotic Nyangatom, Muguji for the Surmic Koegu, Galab for the Cushitic Dassanach, Marale or Ulde for the Cushitic Arbore. The population of Hamar, according to the 2008 national census, is estimated to be 46,000 individuals. Their subsistence can be described as a mixture of pastoralism (keeping cattle, goats and sheep near the Omo valley) and shifting agriculture, i.e. planting sorghum, maize and beans. Although the Hamar appear to lead an ageless, unchanging way of life and established religions such as Islam and Christianity are noticeable only by their absence (Lydall, 1980:147), recently this trend has been changing and, according to our informants, around 100 youths have been converted to Christianity over the past decade.

\section{[2] PREVIOUS STUdiES ON HAMAR}

Some earlier studies and sketches have been mentioned above. These include: Conti Rossini (1927) who published a few grammatical data and a word list; Da Trento (1941) recorded a comparative list of sixty words in Hamar and other neighbouring languages; and Cerulli (1942) who commented on Da Trento and Conti Rossini's contributions.

Over the past few decades some progress has been made in describing aspects of the grammar of the language. Lydall's (1976) article entitled "Hamar" was a grammatical sketch that describes the phonology, morphology and syntax of Hamar in brief. The article, which is quite informative, has for a long time been the only source on Hamar grammar. Later, Lydall published two more studies on Hamar entitled "Gender, Number, and Size in Hamar" (1986) and "Having fun with idiophones: A sociolinguistic look at idiophones in Hamar, Southern Ethiopia" (2000). In the former, Lydall describes how Hamar nouns express gender, number and size with respect to the gender orientation of the society and in the latter she discusses the idiophones of Hamar from a sociolinguistic perspective. The contributions of Lydall were followed by Mary (1987), a senior essay entitled "Hamar Phonology". This paper was partly a duplication of Lydall's paper and provides little linguistic information. Another descriptive study was Getahun (1991), "The Structure of Noun Phrase in Hamar", in which the author described the noun phrase structure of the lan- 
guage within the generative framework. Moges (1999) is unpublished baseline research that describes the basic elements of the language. Cupi et al (2013) entitled "Preliminary notes on the Hamar verb" presents a partial and preliminary description of some verbal forms of Hamar. Recently, two more papers have been published: Binyam \& Moges (2014), the description of copula constructions in Hamar, followed by Moges \& Binyam (2015), "The orthography of Hamar" with an update on the phonology. There are also some historicalcomparative studies made on the Aroid group of languages which includes Hamar ${ }^{1}$. This paper's contribution on the morphophonology of Hamar is part of a larger research undertaking on the grammar of Hamar, under the NORHED Project "Linguistics Capacity Building - Tools for the inclusive development of Ethiopia".

\section{[3] THE PHONOLOGICAL STRUCTURE OF HAMAR}

In this section, the consonant and vowel phonemes, the word structure, the syllable structure and the phonotactic constraints will be discussed in brief.

\section{[3.1] Consonants and vowels}

Hamar has 30 consonant phonemes that include voiceless stops /p, t, k, ?/, voiced stops $/ \mathbf{b}, \mathrm{d}, \mathrm{g} /$ ejectives $/ \mathbf{s}^{\prime} \sim \mathbf{t}^{\prime}, \mathbf{t} \boldsymbol{S}, \mathbf{q}^{\prime} /$ and implosives $/ \boldsymbol{b}, \mathfrak{d}, \boldsymbol{g} /$. In the stop series, Hamar has a four-way contrast between voiceless stops, voiced stops, ejectives and implosives. Fricatives $/ \phi, \mathbf{s}, \mathbf{z}, \int, \chi, \mathbf{h} /$, affricates $/ \mathbf{t s}, \mathbf{t} \int, \mathbf{d} \mathbf{z} /$, nasals $/ \mathbf{m}, \mathbf{n}, \mathbf{y}$ and $\mathbf{n} /$, liquids $/ \mathbf{r}$ and $\mathbf{l} /$ and approximants $/ \mathbf{w}$ and $\mathrm{j} /$ are also part of the phonemic inventory of the language. The alveolar ejective $/ t^{\prime} /$ and the alveolar ejective fricative $/ \mathbf{s}^{\prime} /$ are used interchangeably. It seems that the two consonants are in the process of merging into one in Hamar. In most cases, the fricative ejective occurs. The distribution of these sounds looks partly dialectal, in the sense that in the Hamar dialect where $/ \mathbf{t}^{\prime} /$ is used in some words, the corresponding consonant in the Benna dialect is the alveolar fricative ejective /s'\%. For example, in kut'o 'vulture' in Hamar is pronounced as kus'o in Benna, but this issue is beyond the scope of the present study ${ }^{2}$.

[1] These comparative studies include: Tsuge (1996), Fleming (1974, 1976), Bender (2000, 2003), and Moges $(2005,2007,2015 a)$. Tsuge (1996) presented a preliminary reconstruction of the consonant phonemes of Aroid languages. Fleming $(1974,1988)$ gives the first reconstruction of the consonant phonemes, while Moges (2005) was a description of Hamar pronominals from a historical-comparative perspective and compares the Hamar pronominal system with the rest of Aroid languages. The studies made by Moges (2007) and (2015a) on the historical-comparative Aroid present the reconstructions of the vowel and consonant systems of Aroid languages respectively. These historical-comparative studies have contributed to our understanding of the genetic relationships within the Aroid group and beyond.

[2] A mutual intelligibility test among the Hamar, Benna, Beshada and Kara groups coupled with a lexicostatistics comparison made to determine the level of intelligibility and dialectal variation between these 


\begin{tabular}{|c|c|c|c|c|c|c|}
\hline & Labials & Alveolars & Palatals & Velars & Uvulars & Glottals \\
\hline Stops & $\begin{array}{l}\mathrm{pb} \\
\mathrm{b}:\end{array}$ & $\begin{array}{c}\mathrm{td} \\
\mathrm{t}: \mathrm{d}\end{array}$ & & $\begin{array}{l}\mathrm{kg} \\
\mathrm{k}:\end{array}$ & & $?$ \\
\hline Ejectives & & $\left(\mathrm{s}^{\prime} \sim \mathrm{t}^{\prime}\right)$ & ts & & $\begin{array}{l}q^{\prime} \\
q^{\prime}:\end{array}$ & \\
\hline $\begin{array}{l}\text { Implosives } \\
\text { Affricates }\end{array}$ & 6 & $\begin{array}{c}d \\
(t s)\end{array}$ & $\begin{array}{l}(\mathrm{t})(\mathrm{dz}) \\
\left(\mathrm{t} \int \mathrm{s}\right)(\mathrm{dz}:)\end{array}$ & (g) & & \\
\hline Fricatives & $\begin{array}{l}\phi \\
\phi:\end{array}$ & $\begin{array}{l}\text { s z } \\
\text { s: }\end{array}$ & $\int_{\int:}^{\int}$ & $x$ & & (h) \\
\hline Trills & & $\begin{array}{l}\mathrm{r} \\
\mathrm{r}:\end{array}$ & & & & \\
\hline Laterals & & $\begin{array}{l}\text { l } \\
\text { l: }\end{array}$ & & & & \\
\hline Nasals & $\begin{array}{l}\mathrm{m} \\
\mathrm{m}:\end{array}$ & $\begin{array}{l}\mathrm{n} \\
\mathrm{n}:\end{array}$ & $\begin{array}{l}\text { (n) } \\
\text { (n:) }\end{array}$ & $\begin{array}{l}\mathrm{y} \\
\mathrm{y}:\end{array}$ & & \\
\hline Approximants & W & & $\begin{array}{l}\mathrm{j} \\
\mathrm{j}:\end{array}$ & & & \\
\hline
\end{tabular}

TABLE 1: Consonant Phonemes of Hamar.

Of the 30 singleton consonants identified as phonemes of Hamar, seven consonants $/ \mathbf{s}^{\prime} \sim \mathbf{t}^{\prime}, \mathbf{g}, \mathbf{h}, \mathbf{t s}, \mathbf{t} \int \mathbf{d} \mathbf{3}, \mathbf{n} /$, shown in parenthesis in Table 1 above, are marginal consonants found in a handful of vocabularies. The frequency count made on 2143 tokens, based on 350 basic vocabularies and a six-minute story recorded by native speakers, have shown that these consonants are marginal and found in less than a dozen tokens from the total number of tokens (Moges and Binyam 2015:6-7).

Gemination of consonants is phonemic but not all consonants can be geminated. As shown in the consonant chart in Table 1 above, seventeen consonant phonemes can be geminated, while the remaining thirteen consonants are not geminated. Particularly the implosives, the ejectives, except $/ \mathbf{q} /$, and the glottal consonants $/ \mathbf{l} /$ and $/ \mathbf{h} /$ are among those that are not geminated.

In terms of the distribution of the consonant phonemes, there are fewer restrictions. All voiceless stops, voiced stops, implosives and ejectives are found in all positions within a root or a word. The glottal stop occurs only in word 
initial and medial positions; it is absent from the final position of a word. The sonorants (nasals, trills, liquids and glides) are also found in all positions within a word. An exception is the velar nasal / $\mathbf{y} /$ which cannot appear word initially. Among the nasal consonants, the bilabial and alveolar nasals have a wide range of preconsonantal occurrences, as shown below under phonotactics (Section 3.5).

Hamar also has a fairly complex vowel system, with two sets of vowels that can be distinguished by [ATR] feature. Lydall (1976) recorded a ten-vowel system for Hamar; and Moges (2007:249) reconstructed a ten-vowel system for Proto-Aroid and states that "Proto-South-Omotic or Proto-Aroid must have had a ten-vowel system, which may be distinguished by the feature [ATR]". Vowel length is also phonemic but only the [+ATR] vowels can be lengthened:

\begin{tabular}{|c|c|c|c|c|}
\hline \multicolumn{2}{|c|}{$[+\mathrm{ATR}]$} & \multicolumn{3}{|c|}{ [-ATR] } \\
\hline i i: & $\mathrm{u}$ & $\mathrm{u}:$ & I & $\mathrm{v}$ \\
\hline e e: & 0 & $0:$ & $\mathcal{\varepsilon}$ & 0 \\
\hline a & & & & 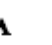 \\
\hline
\end{tabular}

FIGURE 1: The Vowel Phonemes of Hamar.

The consonant and vowel phonemes discussed above are largely in agreement with an earlier study, namely "The orthography of Hamar" by Moges \& Binyam (2015). The only difference in terms of type and number of phonemes is the status of the labio-velar /f/ which was recorded as a phoneme in the earlier study, whereas in this study a closer look has shown that it is a voiceless bilabial fricative $/ \phi /$.

\section{[3.2] Pitch}

A cursory analysis of pitch in Hamar shows that Hamar is indeed a register tone language with two tone levels, high and low. In our data, high tone is marked with an acute accent $\left[{ }^{\prime}\right]$ and low tone with a grave accent [']. Unidentified tone is unmarked. The following minimal and near minimal pairs may illustrate the contrast between the two tone levels: 


\begin{tabular}{|c|c|c|c|}
\hline dáá & 'pot/jar' & Zùlò & 'back' \\
\hline dàà & 'to live' & Zùló & 'level ground' \\
\hline t'áá/s'áá & 'to vomit' & bùlàà & 'open! 2sg. Imp' \\
\hline t'àà/s'àà & 'to milk' & bùláá & 'prostitute' \\
\hline sı 1 & 'fine dust' & dèc̀sá & 'grind! 2sg. Imp.' \\
\hline s 1 & 'nine' & dèc̀sà & 'kill! 2sg. Imp' \\
\hline ع́ćnà & 'men' & àyq'ásí & 'bee' \\
\hline én & 'in the past' & àyq'àsì & 'child of a goat' \\
\hline
\end{tabular}

A detailed and comprehensive analysis of the tone pattern in Hamar, however, awaits further investigation.

\section{[3.3] Word structure}

Hamar word structure can be characterized as having monosyllabic verbal roots and dominantly disyllabic non verbal roots. In what follows, we shall first consider a brief description of the prosody of words in different grammatical categories such as nouns, verbs, adjectives, adverbs, pronouns, Wh-words, post positions, numerals and demonstratives, and then look at the general pattern. The data base used for this analysis contains 1000 lexical items for all word classes.

\section{Nouns}

With regard to the canonical form of simple nouns there are two main types of nouns, namely those ending in a vowel and those ending in a consonant. Those ending in a vowel, when elicited in isolation, carry a terminal vowel (TV). Most nouns which carry these terminal vowels in their citation form drop the vowels when an inflectional or derivational suffix is added to the root form. Examine the following data in (2) that show simple nouns with terminal vowels against the corresponding plural forms to which an inflectional morpheme (the plural marker -na or -no) is added: 


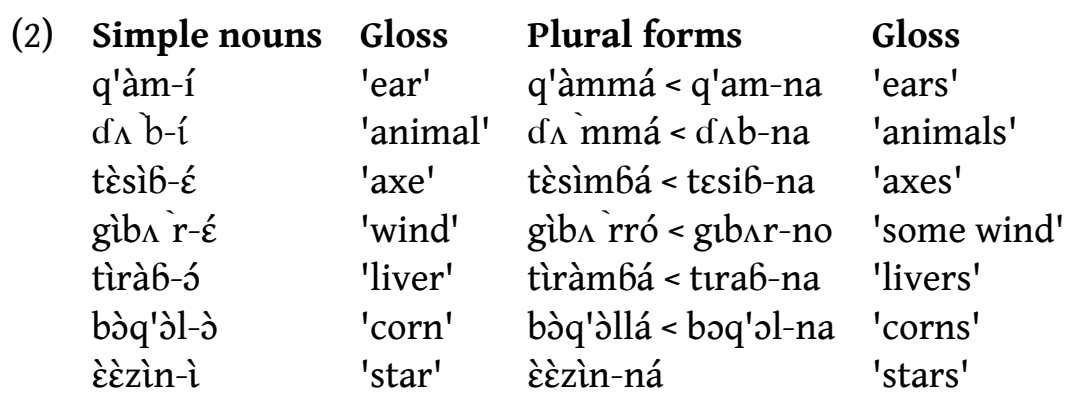

In Hamar the general pattern for number marking in nouns is expressed by attaching the suffix -na for countable nouns and -no for uncountable nouns, as in / 'àn/ 'arm/hand', /2àn-ná/ 'arms/hands'; /isin/ 'sorghum', /isin-o/ 'a stock of sorghum'. In the process of marking the plural forms of nouns, different phonological processes involve creating a phonologically acceptable word that confirms to the phonotactics of the language. See section 4 below for the discussion on morphophonemic processes.

In a few cases, the terminal vowels are not deleted even when an inflectional or derivational affix is attached to the root form. Examine the data in (3) below. In these examples, the terminal vowels remain when a suffix is added to the root noun, perhaps due to phonotactic reasons. For instance, in àp-i-ná without the TV, the final output would result in impermissible sequences of consonants, i.e., an obstruent followed by a sonorant. Hence, the form *apna is not an acceptable word in the language:

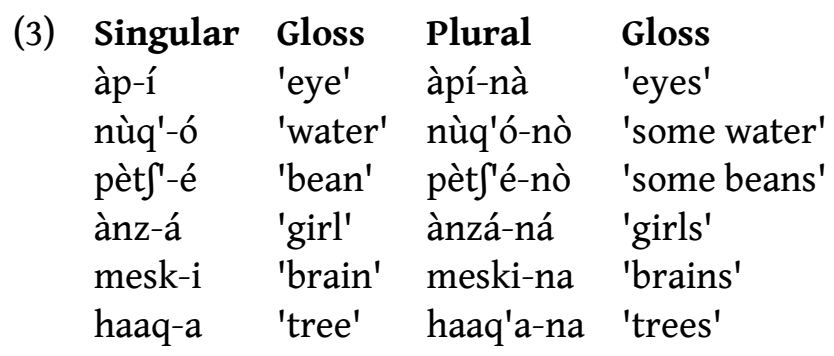

Examine also the following simple roots ending in a consonant in example (4) below. The consonant ending nouns consist solely of the root form.

\begin{tabular}{|c|c|c|}
\hline $\begin{array}{l}\text { Pàn } \\
\int_{\Lambda} \text { n } \\
\text { pànáq' } \\
\text { dàlq }\end{array}$ & $\begin{array}{l}\text { 'hand/arm' } \\
\text { 'urine' } \\
\text { 'frog' } \\
\text { 'news' }\end{array}$ & 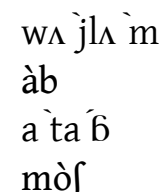 \\
\hline
\end{tabular}

It appears that many of the consonant ending nouns do not have more than 
two syllables and this fact has also been observed in Aari (Hayward 1990), a language closely related to Hamar. By and large, the simple nouns extending to three syllables are those in which the third syllable is the terminal vowel. This fact would lead us to conclude that simple nominal roots rarely exceed two syllables in length, and this in turn reduces the canonical form of Hamar simple nouns to the disyllabic type. Although most nouns in Hamar are disyllabic in nature, there are a few nouns extending to three syllables: dibìnì 'ashes'; bòq'òló 'corn' (Amharic borrowing); sìlàlè 'dust'; kùtòbo' 'fly'; q'ùfùm6a' 'horn'; Èżzìnì 'star'.

The feature of dropping a terminal vowel when a suffix is added to the root noun is a widespread phenomenon in Omotic languages (cf. Hayward 1990 on Aari, Fleming 1990 on Dime). North Omotic languages (and dialects) such as Gamo, Gofa and Dawro are also reported to have the feature of terminal vowels (Hirut 2004). At this stage the issue is far from clear. One possible analysis is to consider the terminal vowels as part of the lexical property of the root, since the quality of the final vowel is unpredictable and there is no discernible pattern in the data at hand. Hayward (1990) and (2001) presents an extensive discussion on terminal vowels in Omotic languages and argues that they do not belong to the root nouns. Rather they seem to be separate and independent of the root noun. Hayward (2001) also classifies the terminal vowels into "stable" and "unstable" terminal vowels, based on the data from languages of the Ometo cluster.

The grammatical function of the terminal vowel is far from clear. At least in Hamar, the terminal vowels cannot be considered as gender markers, for instance, since they are found on both semantically masculine and feminine nouns. They cannot be considered singulative markers either in the sense the term is usually understood, i.e. they do not mark or indicate one item from the group. They also do not seem to mark definiteness, since definiteness is consistently marked by -t- and -to- for masculine and feminine nouns respectively, as in gòngòl-á 'canoe', gòygòl-t-á 'the canoe' (masc. definite), gòygòl-tó-nó 'the canoe' (fem. definite) (See Moges 1999). Following Hayward (1990), we assume for the time being that the final vowels are to a certain extent independent of the root noun and we may consider vowel ending nouns as bipartite in structure. The nature and function of the terminal vowels in Hamar and in the wider Omotic family calls, however, for an in depth analysis of the issue on its own.

Hamar simple nouns, therefore, display the following syllable types: 
(5) Syllable type Example Gloss

$\begin{array}{lll}\text { V } & \text { à.pí } & \text { 'eye' } \\ \text { VV } & \text { c̀̀̀.zì.nì } & \text { 'star' } \\ \text { VC } & \text { àn.zá } & \text { 'girl' } \\ \text { CV } & \text { q'à.mí } & \text { 'ear' } \\ \text { CVV } & \text { pee } & \text { 'country' } \\ \text { CVC } & \text { làn } & \text { 'hand/arm' } \\ \text { CVCC } & \text { dàlq' } & \text { 'news' }\end{array}$

Comparison of the structure of simple nouns with pronouns and numerals shows a slightly different pattern. Pronouns and numerals display only two of the syllable types observed in simple nouns, namely, the CV and CVC types. All pronouns and numerals begin with a consonant and both mono and disyllabic forms are identified in our data. Adjectives also behave like pronouns and numerals in the sense that they begin with a consonant. They also display mono and disyllabic forms but the semantics of the adjectives include the copula and simple adjectives are read as "it is ...". For example, the word for 'red' dè̀ेr is read as 'it is red'. Some examples are given below under (6) and (7) for pronouns and numerals as well as for adjectives respectively:

(6) Pronouns Syllable types

CVC.CV

$\mathrm{CV}$

CV.CV

CV.CV

CV.CV

CV.CV

CV.CV

$\begin{array}{ll}\text { Example } & \text { Gloss } \\ \text { ?ìntá } & \text { 'I' } \\ \text { jà } & \text { 'you } \\ & \text { (sg.)' }\end{array}$

kìdì

kòdì

wòdì

jی dì

kìdì (pl.)'

\section{Numerals}

\section{Syllable types}

CV.CV

CV.CV

CVC.CVC

CVC.CV

$\mathrm{CVC}$

CVC

'they'
CV.CV

\section{Example Gloss \\ kı là 'one' \\ làmà 'two'}

màkkàn 'three'

?òjdì 'four'

dòn 'five'

làx 'six'

tòbà 'seven' 
(7) Adjectives

Syllable type Example Gloss

CV

mo.ra 'blue'

$\mathrm{CVC}$

dìt' 'full'

CVCC

bàr 'young'

CVVC

d ह̀ेेr 'red'

CVV

t'č̀̀.rì 'deep'

Verbs

The simplest form of the verb in Hamar is the second person imperative form in which the vowel -a is suffixed to the root verb. In simple verb forms, as in imperative forms, the syllable types $\mathrm{V}, \mathrm{VV}, \mathrm{VC}, \mathrm{CV}, \mathrm{CVV}, \mathrm{CVC}$ and $\mathrm{CVVC}$ occur. Some examples are the following:

(8) Syllable type

$\begin{array}{lll}\text { VC.V } & \text { àf-à } & \text { 'hide! (2sg. Imp.)' } \\ \text { VV.CV } & \text { c̀ż.là } & \text { 'call! (2sg. Imp.)' } \\ \text { VC.CV } & \text { à.k-á } & \text { 'make/do! (2sg. Imp.)' } \\ \text { CVV } & \text { tfá-á } & \text { 'clap! (2sg. Imp.)' } \\ \text { CV.CV } & \text { jí.?-á } & \text { 'go! (2sg. Imp.)' } \\ \text { CVC.CV } & \text { kùm.m-á } & \text { 'drink (for blood)! (2sg. Imp.)' } \\ \text { CVV.CV } & \text { màà.t-á } & \text { 'return! (2sg. Imp.)' } \\ \text { CVVC.CV } & \text { dòòr.q'-à } & \text { 'sit down! (2sg.Imp.)' }\end{array}$

By contrast, the vast majority of verb roots in Hamar are monosyllabic in their structure having the canonical structure of (C) V (V) (C1) (C2) - as shown in example (9) below:

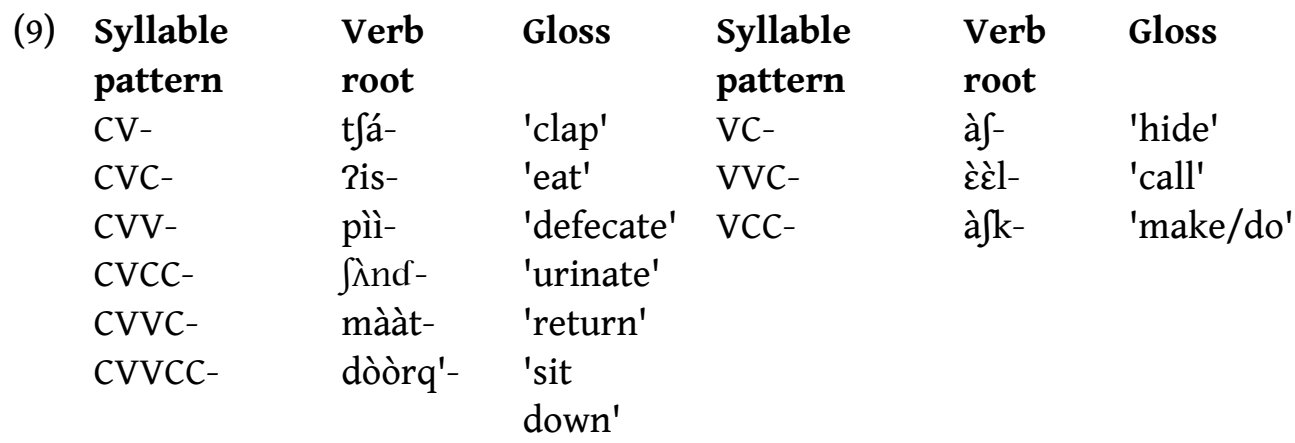

Demonstratives and adverbs

Demonstratives show both open and closed syllable types and the syllable types 
are V, CV, CVV and CVC. Adverbs comprise both open and closed syllables; although many of the forms are monosyllabic they also display disyllabic and multisyllabic words. The syllable types attested in adverbs are CV, CVC and CVV:

(10) Demonstratives

\begin{tabular}{|c|c|c|c|c|c|}
\hline $\begin{array}{l}\text { Syllable } \\
\text { type }\end{array}$ & Example & Gloss & $\begin{array}{l}\text { Syllable } \\
\text { type }\end{array}$ & Example & Gloss \\
\hline $\mathrm{CV}$ & kà & 'this' & $\mathrm{CV}$ & tá & 'still' \\
\hline V.CV & àgà & 'that' & $\mathrm{CVC}$ & t $\int$ 'út & 'never' \\
\hline CV.CV & kìrà & 'these' & $\mathrm{CVV}$ & nàà & 'yesterday' \\
\hline V.CV.CV & ìgìrà & 'those' & & & \\
\hline CVV & sàà & 'there' & & & \\
\hline CVC & $\mathrm{k}_{\Lambda} \int$ & $\begin{array}{l}\text { 'this, here } \\
\text { (M)' }\end{array}$ & & & \\
\hline
\end{tabular}

Wh-words and post positions

Wh-words have both mono and disyllabic forms and the syllable types displayed in the forms include V, CVV, CVCC, CV and CVC. Both open and closed syllables occur within a word. Post positions display a few syllable types of both open and closed. They are also mono and disyllabic forms:

(11) Wh-words

$\begin{array}{llllll}\begin{array}{l}\text { Syllable } \\ \text { types }\end{array} & \text { Examples } & \text { Gloss } & \begin{array}{l}\text { Syllable } \\ \text { types }\end{array} & \text { Examples } & \text { Gloss } \\ \text { V.CVV } & \text { ajii } & \text { 'who?' } & \text { VV } & \text { ì̀ } & \text { 'in' } \\ \text { CVV } & \text { haa } & \text { 'when?' } & \text { VVC.CV } & \text { iinte } & \text { 'inside/in' } \\ \text { CVCC } & \text { harr } & \text { 'what?' } & \text { CV } & \text { tfó } & \text { 'under' } \\ \text { CVC.CV } & \text { hatte } & \text { 'how?' } & \text { CVV } & \text { baa } & \text { 'on/high } \\ & & & & & \text { up' } \\ & \text { hàrnà } & \text { 'why?' } & \text { CVC } & \text { dar } & \text { 'on' }\end{array}$

As a rule, the canonical word structure in Hamar is (C) V (V) (C) (C). Accordingly, the prosodic structure of Hamar words display the following syllable types: V, VV, VVC, VC, CV, CVV, CVC, CVVC and CVCC.

The most common syllable types are the CV and CVC, which are found in all word categories. Pronouns and numerals display only these common syllable types. All word categories demonstrated both open and closed syllables. The most complex syllable type, with an onset and a complex coda, is found in nouns, adjectives and Wh-words whereas a syllable type with a branching nucleus is displayed in verbs, adjectives and Wh-words. 
Generally, unlike the case in many Omotic languages, words can end in a vowel or in a consonant. Words can begin either in a vowel or a consonant. All consonants, except for the velar nasal $/ \mathbf{y} /$, can appear at the beginning of a word. All vowels both short and long can appear word initially, medially and finally.

\section{[3.4] The syllable structure}

The syllable template of Hamar consists of an optional non-branching onset, followed by a branching nucleus and an optional but branching coda: (C) V (V) (C) (C). According to this template, the only obligatory element is the nucleus, while the onset and the coda are optional.

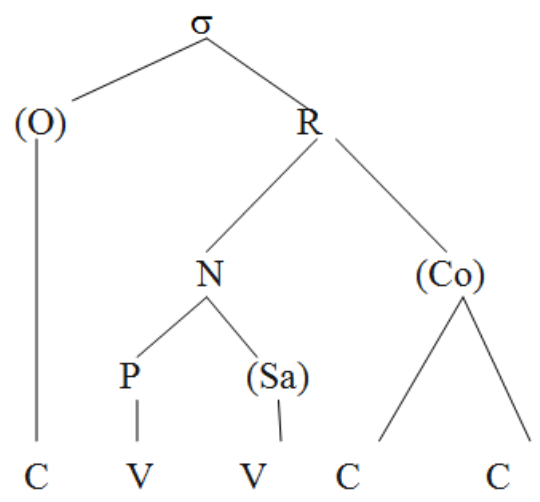

FIGURE 2: The Syllable template of Hamar.

The nucleus which contains a long vowel or a diphthong will be analysed as containing a peak $(\mathrm{P})$ and an adjoining satellite ( $\mathrm{Sa}$ ). The Sa is optional so that a short vowel is simply a nucleus consisting of a bare peak. The coda can also branch having a maximum of two consonants. There are no restrictions on the type of consonants that occur in coda position; all consonants may assume the coda position when coda is non-branching. As for the onset only single consonants may appear in that position and syllables may begin either in a vowel or in a consonant.

Hamar word structure displays the following syllable types: 


\section{(12)}

$\begin{array}{lll}\text { Syllable Type } & \text { Example } & \text { Gloss } \\ \text { V } & \text { a.po } & \text { 'mouth' } \\ \text { VV } & \text { ì̀ } & \text { 'body' } \\ \text { VC } & \text { à̀.pì } & \text { 'moon' } \\ \text { VVC } & \text { iin.te } & \text { 'inside/in' } \\ \text { CV } & \text { kà } & \text { 'this' } \\ \text { CVV } & \text { dáá } & \text { 'pot' } \\ \text { CVC } & \text { Sìn } & \text { 'urine' } \\ \text { CVVC } & \text { dèz̀r } & \text { 'red' } \\ \text { CVCC } & \text { dàlq' } & \text { 'news' }\end{array}$

A branching coda is also part of the complex rhyme in order to subsume clusters of non-identical consonants as well as geminated consonants occurring at medial and final positions within a word. This implies that Hamar allows super-heavy syllables, both word medially and word finally. Hamar is a language that permits a sequence of vowel length and a geminate consonant which means that there are more than three segmental positions within the rhyme of the syllable. Hence, Hamar syllables contain maximally three segments in the rhyme word-internally as shown in (13) below:
(a) CVV.CV poo.li 'tortoise' CVVC.CV pool.la 'tortoises'
(b) CVV.CV zaa.ni 'rope'
CVVC.CV zaan.na 'ropes'
(c) CVV.CV baa.ja 'chicken'
CVVC.CV baaf.ja 'the chicken'
(d) CVVCCV dòò.q'á 'sit down' CVVCCV tiin.ta 'take'

\section{[3.5] Phonotactics}

The phonology of Hamar imposes a number of restrictions on the cooccurrence of consonant phonemes. As a rule, clusters can occur word medially as well as word finally, and no word begins with a cluster of consonants. The word medial consonant clusters occur across syllables.

The permissible combinations of consonant clusters at word medial positions can be divided into four types: 
(i) Type I: Sibilant $+\mathrm{C}$, where sibilants /s/ and /S/ are followed by a consonant

(ii) Type II: Nasal Clusters (NC): a nasal consonant followed by homorganeous obstruent

(iii) Type III: Liquid Clusters (LC): a liquid followed by other sonorants

(iv) Type IV: $\mathrm{N}$ or L followed by a geminate obstruent

The description of each type of clustering is given as follows.

Type I Clusters: Sibilant followed by an obstruent

Type I clusters mainly contain a sibilant as the first member of the cluster and an obstruent as a second member. Some examples:

(14) Clusters Example Gloss sk bı ská 'carry! (2sg. Imp.)'

sk q'àskì 'dog'

sp Wòspà 'crooked'

$\int k \quad g \grave{s} \int k a ́ \quad$ 'against, it is'

Jp gòfpáh 'make beautiful'

Type II Clusters: NC Clusters, a nasal consonant followed by a homorganeous obstruent Type II clusters consist of a nasal consonant as a first member of the cluster, in which case a nasal consonant is followed by a homogeneous obstruent. Some examples are as follows:

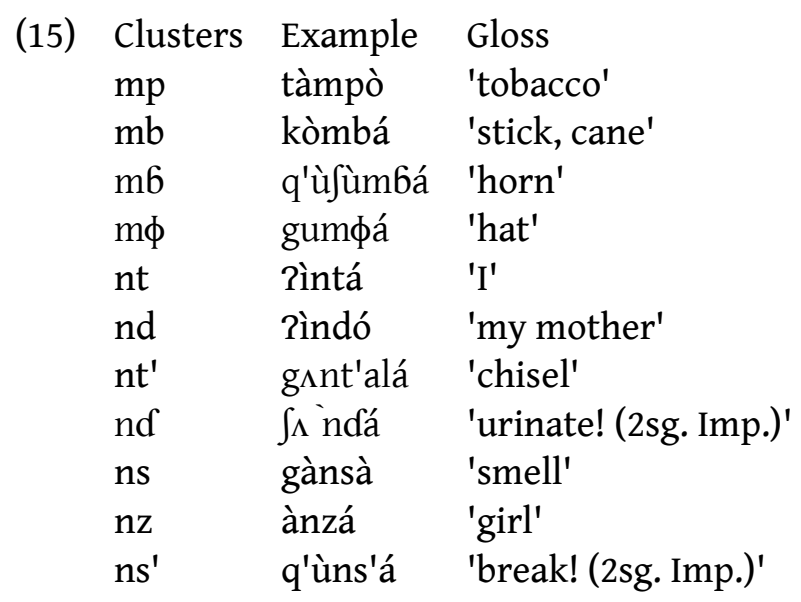




$\begin{array}{lll}\text { yk } & \text { bàykír } & \text { 'arrow' } \\ \text { yq' } & \text { s'ìyq'ré } & \text { 'charcoal' } \\ \text { nt } \int^{\prime} & \text { gànt5'á } & \text { 'slim/thin' } \\ \text { nf } & \text { hànfá } & \text { 'descend! (2sg. Imp.)' }\end{array}$

In Type II there is a further restriction on the choice of the second consonant in the cluster. That is, the second member of the cluster has to be homogeneous to the preceding nasal consonant.

As shown in Section 2.1 above, Hamar has four nasal consonants and they are all phonemic. Single nasals and homorganic nasal clusters contrast as in: q'àmí 'ear', q'àmbi 'dependant orphan'; q'àná 'beat! (2sg. Imp.)', q'àntà 'sorghum store'; lòòya 'shield', pèyká 'time', q'aná 'Maz name for vagina', q'àndzì 'cool'.

\section{Type III Clusters: LC Clusters}

In Type III the sequence consists of a liquid as the first member of the cluster, followed by any consonant as a second member of the cluster. The LC clusters appear to be the most frequent type in the language. Apparently, the preferred consonants in $\mathrm{C} 1$ positions seem to be the liquids. This is not surprising given the fact that as compared to the set of consonants filling the $\mathrm{C} 1$ position, the liquids rank the highest in the sonority scale: ${ }^{4}$

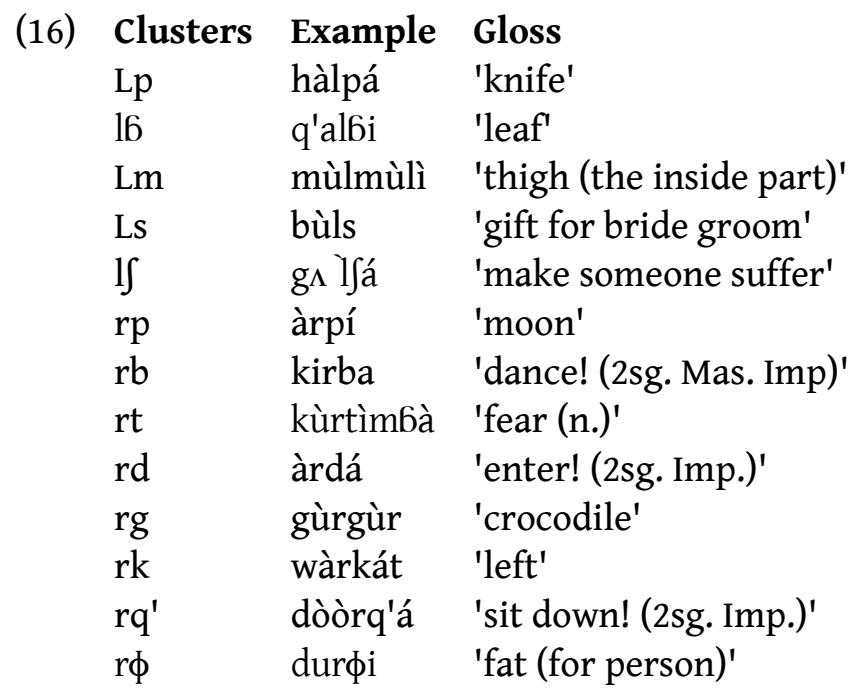

[3] "Maz" is the name of an age-set group that consists of unmarried young people.

[4] Sonority scale or sonority hierarchy as given by Durand (1990:210) refers to energy relative to effort. A sonorous sound is one with high output relative to the articulatory effort required to produce it, and sounds can therefore be ranked according to their degree of sonority. 


\begin{tabular}{|c|c|c|}
\hline rs & фàrsì & 'local beer' \\
\hline $\mathrm{r} \int$ & nàr & 'illness' \\
\hline $\mathrm{rm}$ & Ermet & 'tear (n.)' \\
\hline $\mathrm{rn}$ & hàrnà & 'why?' \\
\hline $\mathrm{rd} 3$ & bárdzó & 'God' \\
\hline $\mathrm{rt} \int^{5}$ & q'òrt f'ì & 'throat' \\
\hline
\end{tabular}

Conversely, when the first member of the cluster happens to be a glide, then the $\mathrm{C} 2$ position is always filled in by a liquid. Again this is in confirmation to the sonority hierarchy that the glides are more sonorous than the liquids. No cluster is found in which both members are liquids:

\begin{tabular}{|c|c|c|}
\hline Clusters & Example & Gloss \\
\hline wl & $\mathrm{t} \int^{\prime} \Lambda \mathrm{wli}$ & 'white' \\
\hline $\mathrm{Jl}$ & $\mathrm{w} \Lambda \mathrm{jl} \mathrm{i} \mathrm{m}$ & 'heart' \\
\hline Js & q'àjsá & 'lose (sth.)' \\
\hline $\mathrm{Jm}$ & kòjmó & 'money' \\
\hline jd & pàjdá & 'count! (2sg. Mas. Imp.)' \\
\hline
\end{tabular}

Type IV Clusters: N/L + Geminate Obstruent

In Type IV a sonorant (more specifically a nasal or a liquid) is followed by a geminated obstruent, creating in effect a sequence of three consonants. This is the result of the morphophonemic alternations taking place at a morpheme boundary:

$\begin{array}{lll}\text { (18) Clusters } & \text { Example } & \text { Gloss } \\ \text { rtt } & \text { màrttidi } & \text { 'I make }(\mathrm{sb}) \text { sell' } \\ \text { nss } & \text { q'anssídi } & \text { 'I make }(\mathrm{sb}) \text { hit' } \\ \text { rdd } & \text { àrddìdì } & \text { 'I make }(\mathrm{sb}) \text { enter' } \\ \text { rqq' } & \text { dòòrqq'ìdì } & \text { 'I make }(\mathrm{sb}) \text { sit down' }\end{array}$

The sequence of three consonants has been created as a result of the morphophonemic alternations that occurred in the process of causativization. The geminated consonant is the result of the assimilation processes that took place at a morpheme boundary in deriving the causative form of the verb. See section 3 below for the details of the morphophonemic alternations.

Word final Clusters

Word final clusters are strictly sequences of a sonorant and an obstruent, i.e. C1 positions are filled in by sonorants and C 2 positions are consistently occupied 
by obstruents:

$\begin{array}{lll}\text { (19) Word final clusters } & \text { Example } & \text { Gloss } \\ \text { Mp } & \text { womp } & \text { 'womb' } \\ \text { r } & \text { nàr } & \text { 'illness' } \\ \text { Ls } & \text { bùls } & \text { 'gift to the bridegroom' } \\ \text { Lp } & \text { ùlp ùlp } & \text { 'to pass through holes' } \\ \text { Lt } & \text { gìdìgàlté } & \text { 'mid night' } \\ \text { Lk } & \text { delk } & \text { 'a problem' }\end{array}$

Geminated consonants ( $\mathrm{C} 1 \mathrm{C} 1)$, or sequences of identical consonants, display a parallel structure in their occurrence to that of sequences of non-identical consonants ( $1 \mathrm{C} 2)$. Most geminates occur word medially. Geminates can also occur word finally for a few consonants (mostly sonorants $[\mathbf{m}, \mathbf{l}, \mathbf{r}]$ and the alveolar fricative $[\mathbf{s}]$ ). Word final geminates are more readily noticeable in idiophones. No word begins with a geminated consonant and not all consonants can be geminated in Hamar, as shown above under 3.1. Most of the geminate consonants occur in morphologically complex forms, and are obviously the result of consonant assimilation across morpheme boundaries. The consideration of morpheme internal contrasts suggests that underlying gemination is far less common. The following geminate examples are all morpheme internal:

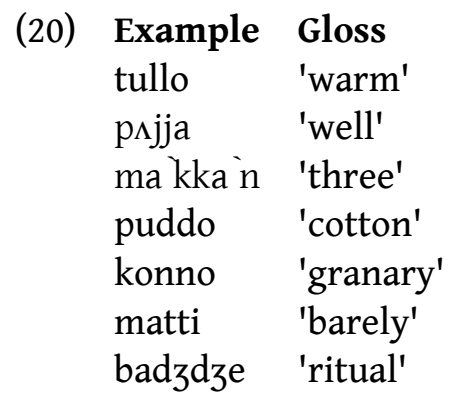

\section{[4] MORPHOPHONEMIC PROCESSES}

The most productive morphophonemic processes prevalent in the morphology of Hamar include nasalization, assimilation of place and manner of articulations, metathesis and sibilant harmony. Some of these processes are motivated or triggered by either the syllable structure conditions or the word structure well-formedness conditions.

\section{[4.1] Nasalization}

The process of nasalization, i.e. the process of changing a non-nasal (in this 
case an obstruent) into a nasal consonant, is a widespread phenomenon. The spreading of nasality, however, does not affect sonorant consonants; it only affects obstruents.

In number marking of nouns, the most productive number marker -na is suffixed to the root noun as in ?àn 'hand/arm'; ?àn-ná 'hands/arms'. The suffix initial consonant, which is a nasal, turns a non-nasal consonant, i.e. an obstruent, into a nasal consonant, as a result of the spreading of nasality that goes from right-to-left:

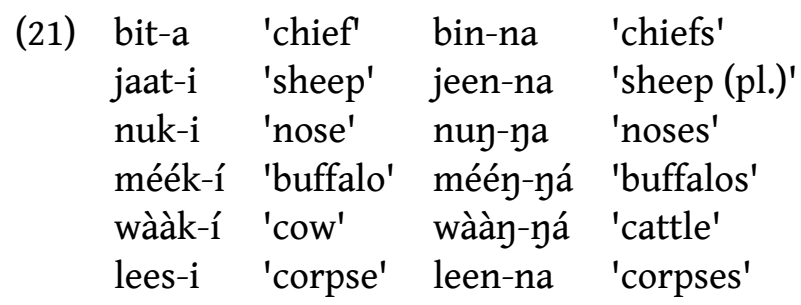

In the first two examples given in (21) above, when the plural suffix is attached to the root form, the nasality feature spreads from the suffix initial consonant to the root-final obstruent, in effect altering the root final consonant to agree in nasality to the following consonant as in $\mathrm{tn}>\mathrm{nn}$. This process is triggered by the phonotactic constraint that the sequence -tn- is an impermissible cluster in the phonology. In the following examples, the -kn- sequence, which is created at a morpheme boundary by the word formation process of affixation, is changed to yy sequence due to the spreading of nasality from right to left. This process is followed by a spreading of place of articulation from left-toright resulting in a complete progressive assimilation. Interestingly, while nasality spreads from right to left regressively, place of articulation spreads from left to right progressively.

Examine the data in (22) below, where nasality does not affect sonorant consonants but the spreading of manner of articulation alters the suffix initial consonant:

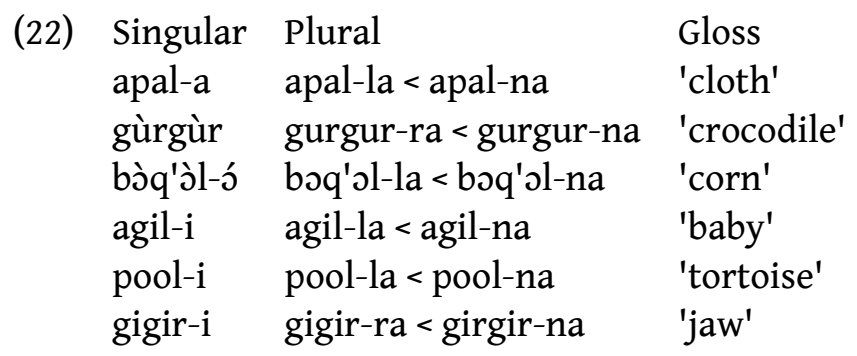

Hence, when the verb root ends with a sonorant, the suffix initial consonant 
agrees with the root final consonant in manner of articulation, as in rn > rr. This is a spreading of manner of articulation from left to right, progressively resulting in a geminate consonant.

On the other hand, when the root final sonorant is a nasal consonant (which has the same manner of articulation with the suffix initial consonant), the spreading of feature becomes that of place of articulation, as shown in (23) below:

$\begin{array}{lll}\text { Singular } & \text { Plural } & \text { Gloss } \\ \text { am-i } & \text { am-ma }<\text { am-na } & \text { 'breast' } \\ \text { am-o } & \text { am-mo }<\text { am-no } & \text { 'field' } \\ \text { q'àm-ì } & \text { q'am-ma < q'am-na } & \text { 'ear' }\end{array}$

In the above examples in (23), the spreading of place of articulation takes place from left to right, in which case the suffix initial consonant must agree in place of articulation with the preceding root final consonant as in $\mathrm{mn}>\mathrm{mm}$, again creating a geminated consonant.

The spreading of the feature nasality to a non-nasal consonant across a morpheme boundary can be schematically represented as follows:
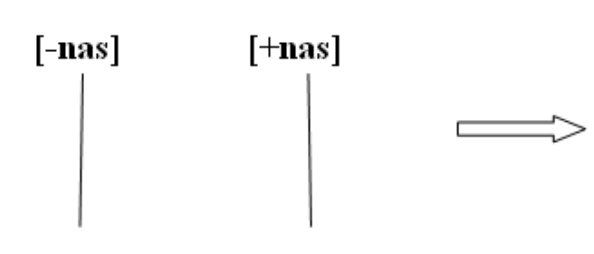

b i t -

n a /
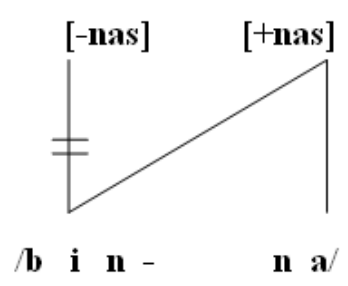

FIGURE 3: Spreading of nasality.

The feature [+nasal] spreads from the suffix-initial nasal consonant to the next segment to its left, i.e. to the root final non-nasal consonant. As a result the association line linking the [-nasal] feature is de-linked.

\section{[4.2] The spreading of Place of Articulation}

When the plural marker -na attaches to the root noun that ends in an implosive consonant, a sequence of $\mathrm{bn}$ or $\mathrm{dn}$ is created, an obstruent followed by a nasal. The spreading of place of articulation takes place from left to right, changing the sequence $6 n$ to $6 \mathrm{~m}$. Nevertheless, the sequence of obstruentsonorant is a violation of the phonotactic structure. In order to conform to the phonotactic structure of the language the process of metathesis applies, chang- 
ing the obstruent-sonorant sequence $6 \mathrm{~m}$ into a sonorant-obstruent sequence as in $\mathbf{m b}$. The spreading of place of articulation from left to right is followed by the process of metathesis as in $6 n>6 m>m b$. Examine the following data in (24):

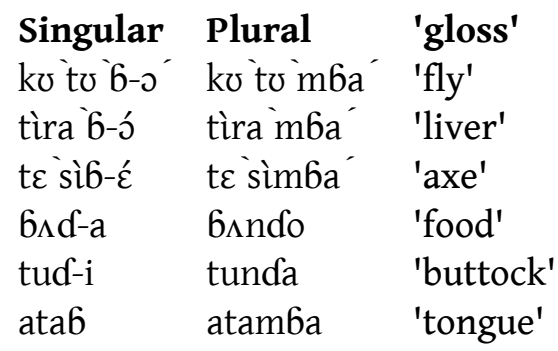

The representation of place assimilation rule in which the nasal agrees in terms of place of articulation with the preceding stop by sharing the place node, can be schematically shown as in figure 4 below:

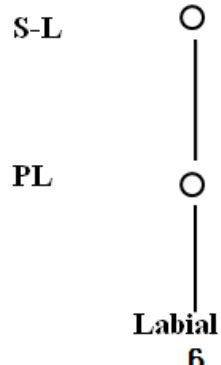

6
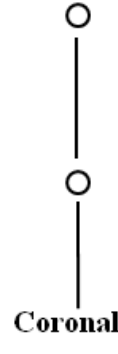

n

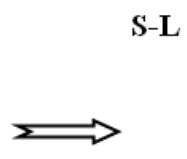

PL

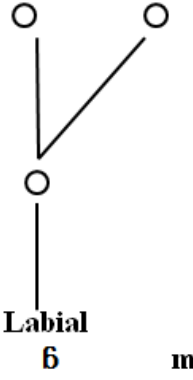

$\mathbf{m}$

FIGURE 4: Place assimilation.

The schematic figure in (4) captures the idea that the segment undergoing assimilation comes to share its PLACE node (PL) with the preceding sound. In other words, a cluster $6 \mathrm{~m}$ arises by assimilation from $6 \mathrm{n}$, so that the $/ \mathrm{m} /$ is identical to the /6/ in all its supra-laryngeal (S-L) features except manner. The nasal loses its PLACE and takes the PLACE node of the preceding stop.

In a nutshell, as shown in the preceding discussions, nasality spreads from right to left altering the root final consonant, so that an obstruent that immediately precedes a nasal consonant at a morpheme boundary must be replaced by the corresponding nasal. Often the spreading of nasality is followed by the spreading of place of articulation which spreads from left to right, i.e. in the opposite direction. In other words, while nasality is regressive, the spreading of place is progressive and this direction of change is consistent and it is the general pattern. With the sonorant ending roots, however, the process of nasaliza- 
tion does not apply; rather it is the spreading of place and manner features that take place from left to right.

In the formation of homorganic nasals the spreading of place of articulation applies to ensure that an obstruent that immediately precedes the nasal consonant must agree in place of articulation. This is followed by the process of metathesis which is triggered by a phonotactic constraint.

\section{[4.3] The spreading of Manner of Articulation}

i) Causative verb

In the derivation of verbs, the causative form is derived from the verb root by attaching the suffix - $t$ or $-\mathbf{s}$ to the root form of the verb. The two forms (allomorphs) seem to be conditioned phonologically, but there are also exceptions. The -s form attaches to the verb roots that end in sonorant consonants, while the - $t$ form attaches to verb roots that end with vowels and obstruent consonants. Although the phonetic motivation for the distribution of the allomorphs is not clear, for the time being we consider the -t suffix as the underlying form of the causative morpheme, since it has a wider distribution.

Compare the following derivations in (25) below for the verbs wadim'work', ?al- 'ward off', and kumm- 'drink (for blood)', where the causative form -s is attached to the verb root followed by a tense marker:

$\begin{array}{ll}\text { Pìntá wadima } & \text { 'I work' } \\ \text { Pìntá wadim-idi } & \text { 'I worked' } \\ \text { Pìntá wadim-s-idi } & \text { 'I make (sb) work' } \\ \text { Pala } & \text { 'ward off' } \\ \text { Pal-s-idi } & \text { 'cause to ward off' } \\ \text { Pìntá kùmmá } & \text { 'I drink' (for blood)' } \\ \text { Pìntá kùmm-ídì } & \text { 'I drank' } \\ \text { Pìntá kùmmí-s-ìdì } & \text { 'I make (sb) drink' }\end{array}$

Examine the following data in (26) below where verb roots that end in vowels attach the causative form $-\mathbf{t}$ followed by tense marker:

\begin{tabular}{|c|c|c|}
\hline (26) & Pinta tii-idi & 'I took' \\
\hline & Pinta tii-t-idi & 'I make (sb) take' \\
\hline & Pinta gi-idi & 'I told' \\
\hline & Pinta gi-t-idi & 'I make (sb) tell' \\
\hline & Pinta kurt-idi & 'I feared' \\
\hline & ?inta kurt-t-idi & 'I make (sb) fear' \\
\hline
\end{tabular}


On the other hand, when the verb root ends in alveolar consonants such as [s] and [d], the root final consonant assimilates to the suffix initial consonant in manner of articulation resulting in a regressive total assimilation process. Examine the data in (27) below:

$\begin{array}{llll}\text { Root verb } & \text { Gloss } & \text { Causative verb } & \text { Gloss } \\ \text { 2is- } & \text { eat } & \text { 2ittidi }<\text { ?is-t-idi } & \text { 'cause }(\mathrm{sb} .) \text { to eat' } \\ \text { q'ad- } & \text { wear } & \text { q'attidi }<\text { q'ad-t-idi } & \text { 'cause }(\mathrm{sb} .) \text { to wear' } \\ \text { s'ás- } & \text { vomit } & \text { s'áttídi }<\text { s'as-t-idi } & \text { 'cause }(\mathrm{sb} .) \text { to vomit' } \\ \text { mars- } & \text { sell } & \text { marttidi }<\text { mars-t-idi } & \text { 'cause }(\mathrm{sb} .) \text { to sell' }\end{array}$

As can be observed from the data in (27) above, the causative marker - $t$ is suffixed to the root verb followed by the past tense marker -idi. In the process of affixation, the root final consonant assimilates to the suffix initial consonant, as in the following derivations: Ris-t-idi > Rittidi. The particular process involved in this derivation is assimilation of manner of articulation, in which the alveolar fricative $[\mathbf{s}]$ has been changed into an alveolar stop $[\mathbf{t}]$. In other words, this is the spreading of manner of articulation from right to left regressively.

Interestingly, when the root verb ends in clusters of consonants involving the liquid as in mars- 'sell' and kurt- 'fear', the assimilation process results in a sequence of three consonants -rtt- word internally, in which case the first member of the cluster is a liquid followed by a geminated stop.

\section{ii) Definiteness}

Definiteness is marked by suffixing - $\mathbf{t}-$, -to and -na to masculine, feminine and plural nouns respectively. Examine the following examples:

(28)

$\begin{array}{lll}\text { Masculine } & \begin{array}{l}\text { Indefinite } \\ \text { agil-a } \\ \text { 'a child(mas)' }\end{array} & \begin{array}{l}\text { Definite } \\ \text { agil-t-a }\end{array} \\ \text { Feminine } & \text { agil-no } & \text { 'the child (mas)' } \\ & \text { 'a child (fem)' } & \text { agil-to-no } \\ \text { Plural } & \text { agil-la< agil-na 'children' } & \text { 'the child (fem)' } \\ & \text { agil-la-na } \\ & \text { 'the children' }\end{array}$

In agil-a the masculine marker is attached to the root form and in agil-no the feminine marker is attached to the nominal root. But in agilla (< agil-na the plural form), there is an assimilation of manner of articulation of the root final consonant to the following suffix when a plural suffix attached. In (29) below, the spreading of manner of articulation occurs at a morpheme boundary dur- 
ing the word formation process:

\begin{tabular}{|c|c|c|c|}
\hline $\begin{array}{l}\text { (29) Root noun } \\
\text { baaf-a } \\
\text { ànq'ás-ì } \\
\text { kojis-i }\end{array}$ & $\begin{array}{l}\text { Masculine definite } \\
\text { baaf-fa } \\
\text { ànq'ás-sà } \\
\text { kojit-ta }\end{array}$ & 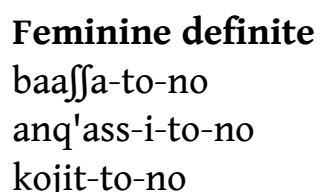 & $\begin{array}{l}\text { gloss } \\
\text { 'chicken' } \\
\text { 'bee' } \\
\text { 'calabash' }\end{array}$ \\
\hline
\end{tabular}

In the first example of the masculine definite form, baaf-ta becomes baaf- $\int \mathbf{a}$ and the sequence of $\int \mathfrak{t}$ changes into $\iint$. In the second example, anq'as-ta becomes anq'as-sa, again st > ss. In the third case, the same change has occurred, i.e. st > ss. All the changes are cases of the spreading of manner of articulation from left to right progressively.

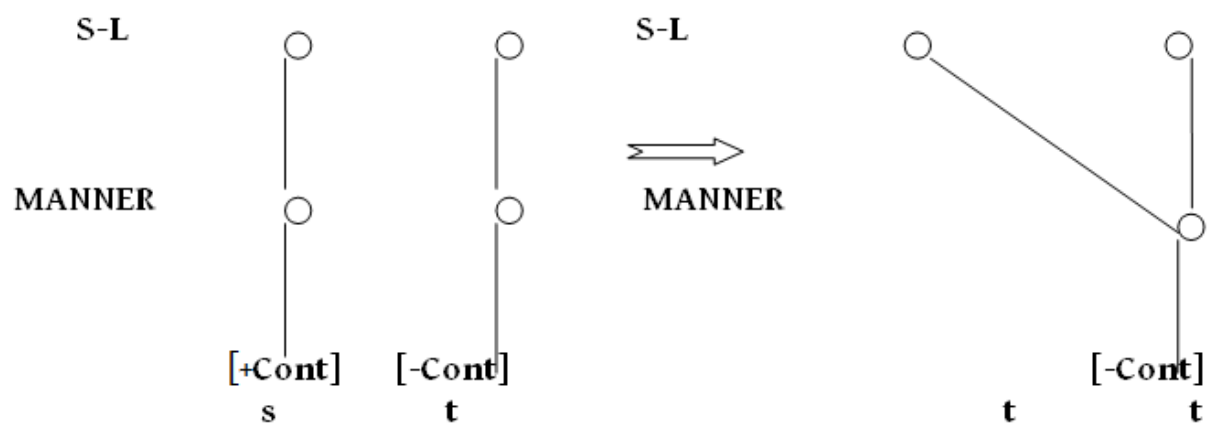

FIGURE 5: Manner assimilation.

The schematic representation in figure 5 shows that the segment undergoing assimilation shares its MANNER node with the following sound. In other words, a sequence $\mathbf{t t}$ arises by total assimilation from st, so that the segments become identical in all their supra-laryngeal features.

\section{[4.4] Sibilant harmony}

Sibilant harmony is a well-formedness condition in nouns and verbs, which is also observed in many Omotic languages such as Aari, Basketo, Bench, Dime, Dizi, Mocha and Zayse (Hayward 1988, Azeb 2012). In Hamar when two or more sibilant consonants occur in a word, they must agree in terms in palatalization, either [+palatal] or [-palatal]: 
(30)

\begin{tabular}{|c|c|}
\hline So $\mathrm{ji}$ & 'guest' \\
\hline$S^{\prime} \Lambda n s^{\prime} i$ & 'to forge' \\
\hline s'ásá & 'vomit! (2sg. Imp) \\
\hline s'os'i & 'many' \\
\hline $\int \Lambda \mathrm{n} \int \mathrm{a}$ & 'sell! (2sg. Imp) \\
\hline $\mathrm{t} \int$ 'at $\int^{\prime} \mathrm{e}$ & 'roots' \\
\hline
\end{tabular}

The same process has also been observed in the derivation of the causative verb where the causative marker $-\mathbf{t}$ changes into $-\int$ following a root final palatal consonant as shown in (31) below:

\begin{tabular}{|c|c|}
\hline hànf-ídì & 'I descended' \\
\hline 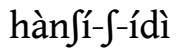 & 'I make (sb) descend' \\
\hline pof-idi & 'I tore' \\
\hline $\int \mathrm{i}-\int-\mathrm{i} d \mathrm{i}$ & 'I make (sb) tear' \\
\hline$\Delta \mathrm{t} \int-\mathrm{idi}$ & 'I finished' \\
\hline$\Delta \mathrm{t} \int \mathrm{i}-\mathrm{t} \int \mathrm{-id}$ & 'I make (sb) finish' \\
\hline
\end{tabular}

Once again this is the spreading of manner of articulation from left to right, progressively altering the suffix initial stop and changing it to a palatal consonant, so that it agrees with the palatal consonant within the root in terms of manner of articulation.

\section{[5] SUMMARY}

This study tries to describe the widespread morphophonemic alternations in Hamar morphology. A brief account of the phonological structure of the language focusing on syllable structure, phonotactic constraints and word structure conditions that regulate the morphophonemic alternations has also been given. The paper also describes the most common morphophonemic processes, such as nasalization, assimilation of place and manner of articulations, metathesis and sibilant harmony in the light of syllable based constraints and morpheme structure conditions. Three productive processes occurring at morpheme boundaries are the spreading of nasality from right to left, and the spreading of place and manner features from left to right.

\section{AC KNOWLEDGMENTS}

This research is sponsored by the NORHED Project - tools for inclusive development for Ethiopia and the author would like to acknowledge the generous support provided by NORAD. The data were collected in a series of fieldwork conducted by the author between 2013-2016 (twice a year for a couple of weeks) 
in the Hamar country and in adjacent towns, such as Jinka as well as in Hawassa, the capital of the southern region. The author would like to express his gratitude to the native speakers of Hamar who provided all the data with both interest and patience. Thanks are particularly due to Shanko Muka, Bazo Morfa and Fora Garsho, who were the principal language consultants throughout the fieldwork period. The author is also grateful to the four reviewers who gave critical comments and suggestions on an earlier version of this paper. All remaining errors, however, are those of the author.

\section{REFERENCES}

Azeb Amha. 2001. The Maale Language. Leiden: CNWS Publications.

Azeb Amha. 2012. Omotic in The Afro-asiatic languages, edited by Zygmunt Frajzyngier \& Erin Shay, 423-500. Cambridge University Press: Cambridge.

Bender, Marvin Lionel. 2000. Comparative Morphology of the Omotic Languages. Munchen.

Bender, Marvin Lionel. 2003. Omotic Lexicon and Phonology. Carbondale: Southern Illinois University.

Binyam Sisay Mendisu. 2008. Aspects of Koorete verb morphology. PhD disertation. Oslo: Department of Linguistics and Scandinavian Studies, University of Oslo.

Binyam Sisay Mendisu \& Moges Yigezu. 2014. Notes on Copula Construction in Hamar, Studies in Ethiopian Languages, 3 (2014), 71-82.

CSA (Central Statistics Agency). 2008. Ethiopia: Statistical Abstract. Central Statistical Agency. Addis Ababa.

Cerulli, Enrico. 1942. Il linguaggio degli Amar Cocche e quello degli Arbore nella zona del lago Stefania. Rassegna di Studi Etiopici 2, 3, 260-272.

Conti Rossini, Carlo. 1927. Sui linguaggi parlati a nord dei laghi Rodolfo e Stefania. In: Boas, F. et al. (eds.). Festschrift Meinhof, 247-255. Hamburg: Friederichsen \& Co.

Cupi, Loredana et al. 2013. Preliminary notes on Hamar verb. In Proceedings of the 5th International Conference on Cushitic and Omotic Languages, eds. Martine Vanhove and Marie-Claude Simeone-Senelle. Rudiger Koppe: Cologne.

Da Trento, Gabriele. 1941. Vocaboli in lingue dell'Etiopia meridionale. Rassegna 
di Studi Etiopici 1, 203-207.

Durand, Jacques. 1990. Generative and non-linear Phonology. Longman Linguistics Library. Routledge.

Fleming, Harold. 1974. Omotic as an Afroasiatic Family. Studies in African Linguistics, Supplement 5, 81-94.

Fleming, Harold. 1976. Omotic Overview. In In Marvin Lionel Bender (ed.), The Non-Semitic Languages of Ethiopia, 299-323, East Lansing: African Studies Centre, Michigan State University: Michigan.

Fleming, Harold. 1988. Proto-South-Omotic or Proto-Somotic Consonant Phonemes: Stage One. In M. Bechhuaus-Gerst and F. Serzisko (eds), CushitcOmotic: Papers from the International Symposium on Cushitic and Omotic Languages, 163-175. Cologne, January 6-9, 1986, Hamburg: Buske.

Fleming, Harold. 1990. A Grammatical Sketch of Dime (Dime-Af). In R. Hayward (ed.), Omotic Language Studies, 494-583, School of oriental and African Studies, University of London.

Getahun Amare. 1991. The Structure of Noun Phrase in Hamar. M.A thesis in Linguistics. Addis Ababa University.

Hayward, Richard J. 1988. Remarks on Omotic sibilants. In Cushitic-Omotic. Papers from the International Symposium on Cushitic and Omotic Languages. Cologne, January 6-9, 1986, Marianne Bechaus-Gerst and Fritz Serzisko (ed.), 261-299. Hamburg: Helmut Buske Verlag.

Hayward, Richard J. 1990. Notes on the Aari Language. In Richard J. Hayward (ed.), Omotic Language Studies, 425-493, School of Oriental and African Studies, University of London.

Hayward Richard J. 2001. A further consideration of terminal vowels in Ometo. New Data and New Methods in Afroasiatic linguistics. Robert Hetzron in Memoriam, Andrzej Zaborski (ed.), Wiesbaden: Harrassowitz, 74-98.

Hirut Wolde-Mariam. 2004. A grammar of Haro. PhD dissertation. Institute of African Studies, University of Cologne.

Lamberti, Marcello. 1991. Cushitic and its classification. Anthropos 86. 1991, 55261.

Lamberti, Marcello. 1993. 'The Ari-Benna Group and Its Classification” Studi Ital- 
iani di Linguistica Teorica e Applicata 22, no. 1, 39-87.

Lydall, Jean. 1976. Hamar. In M.L. Bender (ed.), The Non-Semitic Languages of Ethiopia, pp. 393-438, East Lansing: African Studies Center, Michigan State University. Michigan.

Lydall, Jean. 1980. History and social organization: the case of Widows in Hamar. Working papers on Society and History in Imperial Ethiopia: The Southern Periphery from the 1880s to 1974, eds. Donald Donham and Wendy James, 147156. Cambridge: Cambridge University Press.

Lydall, Jean. 1986. Gender, number and size in Hamar. In: M. Bechhaus-Gerst and F. Serzisko (eds.), Cushitic and Omotic. Papers from the International Symposium on Cushitic and Omotic Languages, Cologne, January 6-9, 1986, 77-90. Hamburg: Helmut Buske Verlag.

Lydall, Jean. 2000. Having fun with ideophones: A socio-linguistic look at ideophones in Hamar, southern Ethiopia. In: Baye Yimam et al. (eds.), Ethiopian Studies at the End of the Second Millenium. Proceedings of the XIVth International Conference of Ethiopian Studies, November 6-11, 2000, vol. III, 886-911. Addis Ababa: Institute of Ethiopian Studies.

Mary Yohannes. 1987. Hamar Phonology. B.A thesis in Linguistics. Addis Ababa University.

Moges Yigezu. 1999. Hamar: A South Omotic Language. A project sponsored by the House of Federation of the Federal Democratic Republic of Ethiopia. Addis Ababa. Mimeographed.

Moges Yigezu. 2005. Some observations in the pronouns of Hamar: A comparative perspective. In Cushitic-Omotic Studies 2004, edited by Yoichi Tsuge, 113132. Kanazawa University.

Moges Yigezu. 2007. The vowel system of Kara from a historical-comparative perspective. "From Beyond the Mediterranean": Akten des 7, internationalen Semitohamitistenkongresses (VII. ISHaK), Berlin 13-15 September 2004, Rainer Voigt (ed.), 245 -252. Aachen: Shaker Verlag.

Moges Yigezu. 2015a. Is Aroid Nilo-Saharan or Afro-Asiatic? Some evidences from phonological, lexical and morphological reconstructions, In NiloSaharan - Models and Descriptions, Angelika Mietzner \& Anne Storch (eds.), 381-401. Koln: Rudiger Koppe Verlag.

Moges Yigezu. 2015b. The Hamar-Benna Cluster: a Lexicostatistics survey. Jour- 
nal of Ethiopian Studies (JES), vol. 38, 1-32.

Moges Yigezu \& Binyam Sisay. 2015. The orthography of Hamar. Studies in Ethiopian Languages, vol. 4 (2015), 1-16.

Trask, Robert Lawrence. 1996. A dictionary of phonetics and phonology. Routledge: London and New York.

Tsuge, Yoichi. 1996. On the consonant correspondences of South Omotic languages. In Shun Sato and Eisei Kurimoto (eds.), Essays in Northeast African Studies, Senri Ethnological Studies 43, 163-188, National Museum of Ethnology, Osaka.

Moges Yigezu

Department of Linguistics

Addis Ababa University

moges .yigezu260@gmail.com 